\title{
Reading Strategy on Internet for Enhancing Reading Profiency
}

\author{
Agus Rofi'i \\ (corresponding author) \\ English Language Education Department, Universitas Majalengka \\ Email: agusrafii@unma.ac.id
}

Noermanzah

Postgraduate Program of Indonesian Language Education, Universitas Bengkulu Email: noermanzah@unib.ac.id

APA Citation: Rofi'i, A. \& Noermanzah, N. (2021). Reading strategy on internet for enhancing reading profiency. Silampari Bisa: Jurnal Penelitian Pendidikan Bahasa Indonesia, Daerah, dan Asing, 4(1), 93-106. https://doi.org/10.31540/silamparibisa.v4i1.1262

\begin{abstract}
This study aim describes an overview of the research related to second language learners and reading strategies. It also considers the more recent research focusing on strategies of reading English texts on internet. The following questions are addressed: (1) what is strategy of reading English text? (2) What is the kind of reading strategy that appropriate for English text on Internet? (3) How is the strategy of reading English text applied on Internet for enhancing reading proficiency? The research method uses qualitative methods. It aims to find out the appropriate strategy in order to enhance reading proficiency. In collecting the data, the writer uses library research. The data analysis process has been carried out by reading the data, reducing, classifying, analyzing, and interpreting. Based on the results of the analysis, there are six strategies for reading proficiency on the internet to improve reading skills, namely predicting, previewing, scanning, skimming, reading for details, and speed reading. From the final result, the writers know the appropriate strategy of reading English text on internet is speed reading.
\end{abstract}

Keywords: reading strategy, reading profiency, internet

\section{Strategi Membaca di Internet untuk Meningkatkan Kemampuan Membaca}

\begin{abstract}
Abstrak
Penelitian ini bertujuan untuk mendeskripsikan gambaran penelitian yang berkaitan dengan pembelajar bahasa kedua dan strategi membaca. Ini juga mempertimbangkan penelitian yang lebih baru yang berfokus pada strategi membaca teks bahasa Inggris di internet. Pertanyaan-pertanyaan berikut ditujukan: (1) Apa strategi membaca teks bahasa Inggris? (2) Apa jenis strategi membaca yang sesuai untuk teks bahasa Inggris di internet? (3) Bagaimana strategi membaca teks bahasa Inggris yang diterapkan di Internet untuk meningkatkan kemampuan membaca? Metode penelitian menggunakan metode kualitatif. $\mathrm{Hal}$ ini bertujuan untuk mengetahui strategi yang tepat untuk meningkatkan kemampuan membaca. Dalam pengumpulan data, penulis menggunakan studi kepustakaan. Proses analisis data sudah dilakukan dengan cara membaca data, mereduksi, mengklasifikasi, menganalisis, dan mengiterpretasi. Berdasarkan hasil analisis, terdapat enam strategi
\end{abstract}


Agus Rofi'i, Noermanzah

Reading Strategy on Internet for Enhancing Reading Profiency

kemahiran membaca di internet untuk meningkatkan kecakapan membaca yaitu predicting, previewing, scanning, skimming, mebacaca untuk detail, dan membaca cepat. Dari hasil akhir, penulis mengetahui strategi membaca teks bahasa Inggris di internet yang tepat adalah membaca cepat.

Kata kunci: strategi membaca, kemahiran membaca, internet

\section{A. Introduction}

Reading is a lifelong skill to be used both at school and throughout life (Küçükoğlu, 2013). According to Anderson (1981), reading is a basic life skill. It is a cornerstone for a child's success in school and, indeed, throughout life. Without the ability to read well, opportunities for personal fulfillment and job success inevitably will be lost. Reading comprehension (understanding, gaining meaning and interpreting the text) depends on a variety of reader-related, text-related, and situational factors (Wooley, 2011; Hermanudin, 2019; Sari et al., 2020; ). Reading is one of the most important factors in assessing a learner's linguistic competence and the crucial aspect for reading is comprehension that influence of reading proficiency. Reading proficiency plays a great role in understanding a written statement accurately and efficiently. To comprehend an English text is not easy, there are many difficulties of it, especially the text on internet, it needs some strategies that are important in order to enhance reading proficiency. In the traditional view of reading, a novice reader acquires a set of hierarchically ordered sub-skills that sequentially build toward comprehension ability (Dole et al.,1991; Cornor, 2004). Having mastered these skills, readers are viewed as experts who comprehend what they read. Nunan (1991) defined reading in this view is basically a matter of decoding a series of written symbols into their aural equivalents in the quest for making sense of the text. He referred to this process as the 'bottom-up' view of reading. Then in International Education Achievement (IEA) Reading Literacy Study defined reading as the ability to understand and use those written language forms required by society and/or valued by individual. Literacy occurs in a variety of language contexts (e.g., school, home, work, and religious or civic institutions) and involves both a range of competencies and a set of habits and practices, arrayed along various dimensions.

Reading is a receptive and active language process, it means that reader is using the brain in an active way. The reader has to work hard when read the text, they have to do some or all of these are imagining in head, understand clearly what the writer is trying to say, and try to express agreement or disagreement, so reading is the process of recognition, interpretation, and perception of written or printed material. The goal after knowing the strategies of reading English text on internet, the writer hopes it can enhance reading proficiency of the readers. There are many advantages associated with reading. Reading helps in mental development and is known to stimulate the muscles of the eyes. Online reading competence focuses on rapid, purposeful and comprehending. It helps everyone to fluent in reading and comprehends the meaning, when the core vocabulary of a language is mastered (Kang, 2014).

Program for International Student Assessment (PISA) 2000 and 2003 also consistently started that Indonesian students surveyed had serious difficulty in

Silampari Bisa: Jurnal Penelitian Pendidikan Bahasa Indonesia, Daerah, dan Asing Vol. 4, No. 1, June 2021 
using reading as a tool advance and extend their knowledge and skills in other areas, such as daily problem solving. They couldn't comprehend information when it was presented in unfamiliar format and showed a difficulty in understanding texts at the highest level of literacy such as in the internet. That involves thinking about what one is doing while reading. Klein et al. (1991) stated that strategic readers attempt the following while reading; identifying the purpose of the reading before reading, identifying the form or type of the text before reading, and thinking about the general character and features of the form or type of the text. For instance, they try to locate a topic sentence and follow supporting details toward a conclusion; projecting the author's purpose for writing the text, choosing, scanning, or reading in detail, and making continuous predictions.

There are many strategies or some useful techniques of reading, there are many techniques like previewing, predicting, speed reading, etc. Others techniques that have different way and result, it can be used depend on reader case. Actually, there are two main reasons for reading: reading for pleasure and reading for information. In supporting this objective, there are main ways of reading as follows: (1) skimming: quickly running one's eyes over the text to get the gist of it; (2) scanning: quickly going through a text to find a particular piece of information; (3) extensive reading: reading longer texts, usually for one's own pleasure. This is a fluency activity, mainly involving global understanding; (4) intensive reading: reading shorter texts, to extract specific information. This is about what will occur next, based on information obtained earlier, prior knowledge, and conclusions obtained within the previous stages more an accuracy activity involving reading for detail.

Whereas there are many techniques and strategies of reading theories, but in the fact of reading are very different. The learners can read as fast or as slowly as they like. Students can read ten pages in 30 minutes, or take one hour to explore just one page. The students cannot easily do this when speaking or listening. This is one of the big advantages of reading because different people work at different speeds, and different strategy refers to their own skill. In order to be confident and successful in English especially in enhancement of reading proficiency, firstly the readers must be able to read and comprehend the texts in this case the English texts on internet because nowadays people can't avoid the technology that go on rapidly and almost modern people or generally students use internet as their source of information, science, and technology which usually using English. By this situation give the writer ideas to find out the strategy of reading English text on internet for enhancing reading proficiency. Named in Forbes magazine 1994, Tony Buzan the top lecturer on the brain and learning of five international lectures, as the founder of the World Speed Reading Championships, the world memory championships and, inventor of Mind Maps, the thinking tool described as the Swiss army knife of the brain, now used by over 250 million people in the worldwide. Speed reading is technique to get a super memory combines with mind map, and he tends to describe it into the techniques of using this strategy (Buzan \& Buzan, 1994). Slow readers as those who read at a speed of less than 150 words per minute (Fry, 1963). His studies showed that reading is not done by continuous movement of the eyes across the line of text. He found that the actual reading is done when the eyes are still the fixation phase. In 1885 a researcher 
called J M Cattel found that proficient readers actually read printed material in units or chunks whole words or phrases at a time. The following extract of text quoted from popular viral email provides some evidence of this activity. By those researchers, the writer tries to analyze that speed reading nowadays as the appropriate strategy that can be used in reading English text on internet which's supported with mind map, it will effective and efficient because it is not only using speed and distinguish the texts like novel or magazine but speed reading here can be used in many kinds of texts on internet and conclude it in the short time.

In order to be confident and successful in English especially in enhancement of reading proficiency, firstly the readers must be able to read and comprehend the texts in this case the English texts on internet because nowadays people can't avoid the technology that go on rapidly and almost modern people or generally students use internet as their source of information, science, and technology which usually using English. By this situation give the writer ideas to find out the strategy of reading English text on internet for enhancing reading proficiency. One of the problems that the writer wants to explore in this thesis is the kinds of reading strategies that can overcome the difficulties of reading English text on internet, what make the reader difficult in reading. The researcher would like to find out the strategy that appropriate with the readers' ability in order to approach the target for enhancing reading proficiency of the readers. In the discourse and analysis of this thesis, the problem is limited on aspects as followed; the theoretical foundation of reading strategy, appropriate reading strategy that is speed reading, the techniques and tips in using speed reading strategies, and the analysis of English texts on internet.

\section{B. Research Methodology}

The significant factor in a research is the use of research method. In this research, the writer uses qualitative research. Bogdan and Biklen (1982) state that qualitative research is descriptive; the data collected is in the form of words of pictures rather than number. The, qualitative research is concerned with process rather than simply with outcomes or product and tends to analyze their data inductively, which the essential of this research is in meaning (Bogdan \& Biklen, 1982).

Qualitative research is a research of which the data in the form of written and oral words which are descriptively analyzed and not use treat as numbering or statistic form (Moleong, 2013). Broom \& Dozier (1989) state qualitative methodologies refer to research which produce descriptive data people's own written or spoken words and observable behavior. The objective of research of the following scientific procedure is to know what reading strategy is that appropriate for reading English text, especially on internet than it can enhance reader's reading proficiency. Refers to the definition above about research, the writer uses a qualitative research in this writing by the way of making an analysis of reading strategy of English text especially on internet. She makes a systematic description about reading strategy of English text on internet as factual, accurate, and applicable as possible. Then the writer takes the conclusion that qualitative research seeks out the 'why', not the 'how' of its topic through the analysis of 
unstructured information things like interview transcripts and materials for gathering information. So, the most parts of the research will involve theoretical basis such as objectives of reading strategies, some kinds of English text, approaches for enhancing reading proficiency and some tips for increasing reading speed of English text on internet such as emails, notes, feedback forms, photos and videos. The writer also investigated extensively many of books, journals and websites and I relied on these. Book source is data source that is used in this research. To acquire substantive theories, the writer uses many books.

They are classified to be two parts; (1) primary data source, Primary data source of this research is book teaching reading; (2) secondary data source, the writer does not only use the using primary data source, but also uses another data source, secondary data source. Most of secondary data source are in the linguists opinions about theories that deal with research investigational necessity. They are acquired from internet, books, and magazines. The techniques for collecting, the writer finds collects data, both primary and secondary data. In this matter, the writer used library research or theoretical data that is in the form of words. The technique of analysis data that used in this data descriptive analyze because the object of this research is documentation. So, the writer conducts four steps to analyze the data: (1) reading, (2) reducing, (3) classifying, (4) analyzing, and (5) interpretation.

\section{Results and Discussion \\ 1. Results}

Psychologists and educational specialists working on the visual acuity question devised the tachistoscope, which is a machine designed to flash images at varying rates on a screen. The experiment started with large pictures of aircraft being displayed onscreen. The images were gradually reduced in size and the flashing-rate was increased. They found that, with training, an average person could identify minute images of different planes when flashed on the screen for only one five-hundredth of a second. The results had implications for reading.

Using the same methodology, the U.S. Air Force soon discovered that they could flash four words simultaneously on the screen at rates of one five-hundredth of a second with full recognition by the reader. This training demonstrated clearly that, with some work, reading speeds could be increased from reading rates to skimming rates. Not only could they be increased but the improvements were made by improving visual processing. Therefore, the next step was to train eye movements by means of a variety of pacing techniques in an attempt to improve reading. The reading courses that followed used the tachistoscope to increase reading speeds; it assumed that readers were able to increase their effective speeds from 200 to 400 words per minute using the machine. The drawback to the tachistoscope was that post-course timings showed that, without the machine, speed increases rapidly diminished.

Following the tachistoscope discoveries, the Harvard Business School produced the first film-aided course, designed to widen the reader's field of focus in order to increase reading speed. Again, the focus was on visual processing as a means of improvement. Using machines to increase people's reading speeds was 
a trend of the 1940s. While it had been assumed that reading speed increases of $100 \%$ were possible and had been attained, lasting results had yet to be demonstrated.

It was not until the late 1950s that a portable, reliable and 'handy' device would be developed as a tool for increasing reading speed. The researcher was a school-teacher named Evelyn Wood. She was committed to understanding why some people were naturally faster at reading than others and was trying to force her to read very quickly. It is told that while brushing off the pages of the book she had thrown down in despair, she discovered that the sweeping motion of her hand across the page caught the attention of her eyes, and helped them move more smoothly across the page. She then utilized the hand as a pacer, and called it the "Wood Method", which was renamed to Reading Dynamics in 1958. She coined the term "speed reading. More recently, speed reading courses and books have been developed to help the consumer achieve even higher increases in reading speed. With specific reference to pseudoscience concepts, companies have claimed to be able to extract meaning out of consciously unnoticed text from the para-consciousness or subconscious. These courses go by various titles such as photo-reading (1994), and alpha-netics (1999). Reading experts, refer to them as snake oil reading lessons because of their high dependence on the suspension of the consumer's disbelief. Also, some speed reading proponents have taught that certain groups of people are more gifted at speed reading than others (e.g., young children, dyslexics, or those with (ADHD). Speed Reading 4 Kids (2003) and Damn the School System-Full Speed Ahead! (1973) are two books that have advocated speed reading for children, including some learning disabled.

Nowadays, Speed reading becomes a collection of reading strategy which attempt to increase rates of reading without greatly reducing comprehension or retention. Methods include chunking and eliminating subvocalization. No absolute distinct "normal" and "speed-reading" types of reading exist in practice, since all readers use some of the techniques used in speed reading (such as identifying words without focusing on each letter, not sounding out all words, not subvocalizing some phrases, or spending less time on some phrases than others, and skimming small sections. Refers to Forbes magazine that Tony Buzan as the founder of the World Speed Reading Championships, and Buzan's book and the author product related to learning has achieved massive success in more than 150 countries and languages, generating revenues in excess of 100 poundsterling million.

\section{Discussion}

\section{Reading Strategy}

One of the most important points to keep in mind when reading is that there is not one type of reading but several according to one's reason for reading. Student will never read efficiently unless they can adapt their reading speed and technique or strategy to their aim when reading (Block \& Israel, 2005; Sari et al., 2020). By reading all texts in the same way, students would waste time and file to remember and fail to remember points of importance to them because they would absorb too much non-essential information. The strategies in this case should 
make the students more confident and efficient readers. There are many strategies that can be affective for enhancing reading proficiency. However, recent research shows that is simplistic to think that you can enhance your remembering by applying of these strategies to any text, some essential strategies for enhancing reading proficiency are as follows:

\section{Predicting}

In order to be a good reader, learners should set a goal for their reading; therefore, good readers have a purpose for reading. One strategy for improving comprehension is predicting, which helps the reader set a purpose for their reading. Research has shown that good readers use their experiences and knowledge to make predictions and formulate ideas as they read (Block \& Israel, 2005). This strategy also allows for more student interaction, which increases student interest and improves their understanding of the text (Oczkus, 2003). It is important to compare the outcome in the actual text with the prediction process as it will lead the learner to improve his understanding. Reading is an activity involving constant guesses that are later rejected or confirmed, this means that one does not read all the sentences in the same way but rely on a number of words to get an idea of what kind of sentence is likely to follow. The aim of this exercise is to help you to acquire this crucial ability. Before reading a text in detail, it is possible to predict what information may find in it. After looking at the title, for example; it can ask yourself what you know and do not know about the subject before reading the text or it can formulate questions that you would like to have answered by reading the text. These exercises will help focus more effectively on the ideas in a text when you actually start reading to help predict may also use previewing and scanning.

\section{Previewing}

Previewing is a strategy to motivate students to read are trained to use titles, section headings, photo captions to get the sense and content of a reading selection, use tables of contents to get an idea of what passage is about. This exercise will show how much you can guess about a passage by simply looking at its title and the table of contents. Being able to use an index is also essential when scanning to locate specific information. It is also exposed to use the text on the back cover a book, the preface and the table of contents to get an idea of what the book is about. It is often important to be able to get a quick idea of what a book is about (e.g. when buying a book or choosing one in the library).

\section{Scanning}

It is a strategy that use when search for key words or ideas. In most cases, scanning involves moving your eyes quickly down the page seeking specific words and phrases. Scanning is also used find a resource to determine whether it will answer your questions. Once you've scanned the document, you might go back and skim it. In other words, scanning involves rapid reading for the specific rather than the general; for particular details rather than the overall idea. When scanning, look for the author's use of organizers such as numbers, letters, steps, or the words, first, second, or next. Look for words that are bold faced, italics or in a 
different font size, style or colour. Sometimes the author will put key ideas in the margin.

\section{Skimming}

It is used to quickly identify the main ideas of a text, when reading the newspaper probably not reading it word-by-word; instead scanning the text. Skimming is done at a speed three to four times faster than normal reading. People often skim when they have lots of material to read in a limited amount of time and use skimming want to see if an article may be of interest in your research. There are many techniques that can be used when skimming and some people read the first and last paragraphs using headings, summarizes and other organizers as they move down the page or screen. Skimming is therefore a more thorough activity which requires an overall view of the text and implies a definite reading competence. Scanning, on the contrary, is far more limited since it only means retrieving what information is relevant to our purpose. Yet it is usual to make use of these two activities together when reading a given text. For instance, we may well skim through an article first just to know whether it is worth reading, and then read it is of interest. It is also possible afterwards to scan the same article in order to note down a figure or a name which we particularly want to remember. This strategy uses when the readers are going through a newspaper or magazine. This technique is usually employed in conjunction with skim reading. It is especially useful if the readers are looking for specific information which may be contained in a variety of books, journals or articles. The process is one of search and discovery. It requires you to skim read, locate, and mark and then return to close reading.

\section{Reading for Detail}

It involves reading a text thoroughly in order to comprehend the ideas and arguments it contains. In-depth reading is consequently much slower than skim reading, and you may find that you need to read certain sections of a difficult text more than once. When reading in-depth it is useful to; (a) read the opening paragraphs and conclusion first, this will help you to digest the intention and conclusion of the writer prior to a closer reading of the text; (b) go back to the beginning, and read through the whole text, marking out and noting: key words and phrases; ideas, facts, and data you think are important; and the structure of the argument; and (c) make sure you understand the writer's main ideas and arguments, and the overall message of the text.

\section{Speed Reading}

Speed reading is a collection of reading strategy which attempt to increase rates of reading without greatly reducing comprehension or retention. Speed reading is characterized by an analysis of trade-offs between measures of speed and comprehension, recognizing that different types of reading call for different speed and comprehension rates, and that those rates may be improved with practice. There are many programs available that teach different fundamentals, while some are better than others. One of the most common ways of increasing 
reading speed is to have passages to read. A conversion table, taking the length of the text and the reading time into account, will tell what your reading speed is and this will make it easier for the reader to try and read a little faster every time. Reading should also be followed by comprehension questions or activities since reading speed should not be developed at the expense of comprehension.

\section{Speed Reading as an Appropriate Reading Strategy}

The experiment started with large pictures of aircraft being displayed onscreen. The images were gradually reduced in size and the flashing-rate was increased. They found that, with training, an average person could identify minute images of different planes when flashed on the screen for only one five-hundredth of a second. The results had implications for reading. This training demonstrated clearly that, with some work, reading speeds could be increased from reading rates to skimming rates. Not only could they be increased but the improvements were made by improving visual processing. Therefore, the next step was to train eye movements by means of a variety of pacing techniques in an attempt to improve reading. The reading courses that followed used to increase reading speeds; it assumed that readers were able to increase their effective speeds from 200 to 400 words per minute using the machine.

Also, some speed-reading proponents have taught that certain groups of people are more gifted at speed reading than others. Speed Reading 4 Kids and Damn the School System Full Speed Ahead are two books that have advocated speed reading for children, including some learning disabled. Nowadays, Speed reading becomes a collection of reading strategy which attempt to increase rates of reading without greatly reducing comprehension or retention. No absolute distinct normal and speed-reading types of reading exist in practice, since all readers use some of the techniques used in speed. Speed reading is characterized by an analysis of tradeoffs between measures of speed and comprehension, recognizing that different types of reading call for different speed and comprehension rates, and that those rates may be improved with practice.

\section{How to Get Familiar with Speed Reading Strategy}

Familiarize yourself with the content of the text. Read the first paragraph of each section and if the text is short, the first sentence of each paragraph. Eliminate what you don't need - highlight what readers do. 'Park' difficult things and build up an overall picture which will help with the more complex parts. For example, if readers were doing a jigsaw puzzle, reader might start by fitting the edges and corners together, and that some pieces are really easy to place. Others might initially be more difficult, but as readers fit more pieces of the puzzle. Together, the pieces that were once tricky become simple. It's the same with reading the more context or background knowledge you have, the easier it will be to make sense of initially tricky material.

\section{Skimming Speed Reading}

Skim by zooming through the text quickly trying to spot key words. Don't start at the beginning and plod or shuffle through the text. After you have scanned the text and found the bits that you think look relevant and interesting then skim read. 
Concentrates keep your keywords and questions in your mind. Skimming involves searching for the main ideas by reading the first and last paragraphs, noting other organizational cues, such as summaries, used by the author. Skimming is used to quickly identify the main ideas of a text. When you read the newspaper, you're probably not reading it word-by-word; instead you're scanning the text. Skimming is done at a speed three to four times faster than normal reading. People often skim when they have lots of material to read in a limited amount of time. Use skimming when you want to see if an article may be of interest in your research. There are many strategies that can be used when skimming. Some people read the first and last paragraphs using headings, summarizes and other organizers as they move down the page or screen. This technique is useful when you're seeking specific information rather than reading for comprehension. Skimming works well to find dates, names, and places. It might be used to review graphs, tables, and charts.

\section{Glance Randomly through a Book}

Skimming is browsing or glancing randomly through a book. It has great importance in learning and is emphasized as a strategy in speed reading particularly for exam taking. The purpose of skimming is to get an overview not the specific details of the material. It uses to decide if the book, article or report is worth our time, and has anything new and worthwhile to tell us.

\section{Skim Several Times}

When reading extensive material, the reader can first skim over the chapter and section titles to give you an idea of when the material is about. Then quickly scan through the material again to get a better idea of the topic. Finally, the reader reads the assignment, but still reading rapidly.

\section{Skim Everything of Reading Text}

Skimming is a step you should always take before you read any article of factual or practical narrative. The reader will soon be able to detect most important facts, strange vocabulary, and words that are clues to important relationships. It's a good practice to skim everything in mass media or some text, after reading the title and first paragraph. You may get all the information. This keeps your skimming skills from deteriorating, or will give you the practice reader need to develop necessary skills. Skim everything you intend to read before making a final decision to read, discard, or study the material. Skim all highlighting and develop a read skim pattern to use for rapid review. And don't overlook this! Reviewing frequently and rapidly is the best way to memorize or simply remember information from notes and long text assignments.

\section{Scanning Speed Reading}

Scanning is a technique use when looking up a word in the telephone book or dictionary. The readers search for key words or ideas. In most cases, know what looking for, so concentrating on finding a particular answer. Scanning involves moving eyes quickly down the page seeking specific words and phrases. 
First, scanning is also used when finding a resource to determine whether it will answer your questions. Once readers have scanned the document, might go back and skim it. When scanning, look for the author's use of organizers such as numbers, letters, steps, or the words, first, second, or next. Look for words that are bold faced, italics, or in a different font size, style, or colour. Sometimes the author will put key ideas in the margin.

Reading off a computer screen has become a growing concern. Research shows that people have more difficulty reading off a computer screen than off paper. Although they can read and comprehend at the same rate as paper, skimming on the computer is much slower than on paper. Similarly, scanning skills are valuable for several purposes in studying science. First, they are an aid in locating new terms, which are introduced in the chapter. Unless you understand the new terms, it is impossible to follow the author's reasoning without dictionary or glossary. Thus, a preliminary scanning of the chapters will alert you to the new terms and concepts and their sequence. When readers locate a new term, try to find its definition. If readers are not able to figure out the meaning, then look it up in the glossary or dictionary. Secondly, scanning is useful in locating statements, definitions, formulas, etc. which reader must remember completely and precisely. Scan to find the exact and complete statement of a chemical law, the formula of a particular compound in chemistry, or the stages of cell division. Also, scan the charts and figures, for they usually summarize in graphic form the major ideas and facts of the chapter.

\section{Mind Mapping}

After using scanning and skimming use mind mapping to get easy for memorizing and become super memory that put in the long-term memory. The readers use the key words to make simpler and shorter the time. By using the picture or other as representative of the reader comprehension is up to the reader's comprehension, because different reader has different comprehension. There are some auditory learners that using speed reading so they can use this way also to make remember because refers to the research of the teachers committee (Ministry of Education and Culture Republic of Indonesia, 2009), that's only $20 \%$ of the learners who learn by auditory system and by kinesthetics system they can solve it.

\section{Techniques before Reading Strategy}

Effective and efficient readers learn to use many strategies of reading or different purposes. Skimming, scanning, and critical reading are different styles of reading and information processing (Block \& Israel, 2005). Before reading, you need a sense of your own purpose for reading. Knowing purpose in reading helps focus attention on relevant aspects of the text. Take a moment to reflect and clarify what your goal really is in the reading you're about to do. Before reading, you can take steps to familiarize yourself with the background of the text, and gain a useful overview of its content and structure. Seek information about the context of the reading, its purpose, and its general content. Take a look for an abstract or an author's or editor's note that may precede the article itself, and read any background information that is available to reader about the author, the occasion 
of the writing, and its intended audience. Looking at the title and noting general ideas that are tipped off by these cues. Continue flipping pages quickly and scanning paragraphs, getting the gist of what material the text covers and how that material is ordered. After looking over the text as a whole, read through the introductory paragraph or section, recognizing that many authors will provide an overview of their message as well as an explicit statement of their thesis or main point in the opening portion of the text. Taking the background information, the messages conveyed by the title, note or abstract, and the information from the opening paragraph or section into account, you should be able to proceed with a good hunch of the article's direction. In order to become aware of your reading situation ask yourself questions like: consider your purpose; look for specific words and become an impatient reader.

Some students say, what if I think ahead while I am reading but my predictions are wrong. Predicting is useful because all your concentration is focused on the reading and making senses of it. In order to make meaning, while reading speed can use connecting words. Sign words such as and, moreover, also, furthermore tell you that there will be more of the same, while contrast words such as but, although, rather tell you that the message will now go in another direction. The reader might need to change your predictions. Speed readers predict what the text is likely to tell them next, but they are not upset if a prediction is wrong, they quickly adjust their expectations. Different speeds for different material; you do not need to read every word to understand a text; however, some texts will require careful reading, so you need to know when to adjust your reading speed. Skim a text, and then decide if a slower reading approach is necessary.

Practice activity; in order to avoid reading every word the reader must increase the rate your eyes move across the page, choose easy material for practice; sweep your eyes faster across the page than you've ever done before; do not mouth the words; do not even mentally say them; and start with short practice periods, e.g. 3 minutes. Speed Reading can help the reader to read and understand written information much more quickly. This makes it an essential skill in any environment where the readers have to master large volumes of information quickly, as is the norm in fast-moving professional environments. What's more, it's a key technique to learn if the reader suffers from information overload, because it helps reader to become much more discriminating about the information that you consume.

\section{The Experiences of the Readers in Using Speed Reading Strategy}

The student of English study program, states that reading internet text by using speed reading really helpful his understanding and effective way, because speed reading that he known is combined with mind map, it's not only using our speed in reading but also apply it on the written text in the short time. He said also it is really important to use speed reading strategy for all of the readers specially to comprehend English text in teaching learning context it can only use the key words. Speed reading is an effective way, not only for written text like magazine, article, or some English texts, but for Math also because the techniques in speed 
reading can cover all the texts depend on to the reader's purpose. Using speed reading is very interesting way for reading because it is not only using our left brain but collaborate with the right brain. Speed reading is an enjoying strategy, by mind mapping and also become super memory. The writer takes the conclusion that speed reading is the most appropriate reading strategy and almost the people who practice it will get the benefit, effective and efficient in many things.

\section{Conclusion}

Reading strategies help the reader to read in a very efficient way. Using reading strategies is aimed to get the maximum benefit from the reading with the minimum effort. The previous chapters have shown the different strategies to read intelligently and the writer takes the conclusion that speed reading is the appropriate reading strategy. In this life everyone who wants to achieve success must work hard and also in this global community the people face the modern community. Internet as the modern technology that is used for every little thing they do, because internet as digital technology so the people who use it must be understand well, especially in reading the kinds of English text. There are many benefits which the reader will get if they know and practice the appropriate strategy of reading, that strategy is speed reading. At the first time the people will get the difficulties to practice this strategy but step by step they will be used to, and achieve the success to get the reading goal. The reader who wants to enhance their reading proficiency must keep for trying this strategy, will be hard at the first but will be nice in the last.

\section{References}

Anderson, M.T. (1981). Efficient reading: A practical guide. Sidney: McGraw-Hill Book Company.

Block, C. \& Israel, S. (2005). Reading first and beyond: The complete guide for teachers and literacy coaches. Thousand Oaks, CA: Corwin Press.

Bogdan, R. C., \& Biklen, S. K. (1982). Qualitative research for education: An introduction to theory and methods. Boston: Allyn and Bacon.

Broom \& Dozier. (1989). Using research in public relations. New Jersey: Prentice Hall.

Buzan, T. \& Buzan, B. (1994). The mind map book: How to use radiant thinking to maximize your brain's untapped potential. New York: Dutton.

Cornor, C. M. (2004). Effective reading comprehension intruction examining child $x$ intruction. Journal of Educational Psychology, 95(4), 682-693.

Dole, J.A., Duffy, G.G., Roehler, L.R. \& Pearson, P.D. (1991). Moving from the old to the new: Research on reading comprehension instruction. Review of Educational Research, 61(2), https://doi.org/10.3102/00346543061002239 
Fry, E.B. (1963). Teaching faster reading. London: Cambridge University Press.

Hermanudin, Suhartono, Suryadi, \& Noermanzah. (2019). Improvement of reading comprehension ability by using core models of class vii a students of SMP Negeri 10 Bengkulu Tengah. International Journal of Scientific and Technology Research, 8(12). 647-648, http://www.ijstr.org/paperreferences.php?ref=IJSTR-1219-25902

Kang, H. (2014). Understanding online reading through the eyes of first and second language readers: An exploratory study. Computers \& Education, 73(1), 1-8. https://doi.org/10.1016/J.COMPEDU.2013.12.005

Klein, M. L., Peterson, S., \& Simington, L. (1991). Teaching reading in the elementary grades. Needham Heights, Mass: Allyn and Bacon.

Küçükoğlu, H. (2013). Improving reading skills through effective reading strategies. Procedia-Social and Behavioral Sciences. 70. 709-714. http://doi.org/10.1016/j.sbspro.2013.01.113

Ministry of Education and Culture Republic of Indonesia. (2009). Directorate general of quality improvement of teachers and education personal teaching reading. Jakarta: Ministry of Education and Culture Republic of Indonesia.

Moleong, L.J. (2013) Metode penelitian kualitatif. Bandung: PT. Remaja Rosdakarya.

Nunan, D. (1991). Language teaching methodology: A textbook for teacher. Upper Saddle River, NJ: Prentice Hall.

Oczkus L.D. (2003). Reciprocal teaching at work strategies for improving reading comprehension. Newark, DE: International Reading Association.

Sari, M.H., Susetyo, Noermanzah, Wardhana, D.E.C., Kusumaningsih, D. (2020). Understanding the level of students' reading comprehension ability. Universal Journal of Educational Research, 8(5). 848-1855, https://doi.org/10.13189/ujer.2020.080521

Wooley, G. (2011). Reading comprehension assisting children with learning difficulties. London \& New York: Springer. 